\title{
Why Is the Centromere So Cold?
}

\author{
K.H. Andy Choo ${ }^{1}$ \\ The Murdoch Institute for Research into Birth Defects, Royal Children's Hospital, Parkville 3052, Australia
}

\begin{abstract}
C hromosomes are known to contain local hot and cold spots that undergo quite different rates of meiotic recombination. The question of why such regional variation in recombination rates exists on chromosomes holds a strange mix of intrigue and frustration for ge neticists. One of the human chromosomes that has been carefully studied over the years in this regard is the $X$ chromosome. These studies have concentrated on the evaluation of the re combination rates across various subregions of this chromosome and have, by and large, avoided the more recalcitrant centromere domain. In this issue, Mahtani and Willard (1998) present an analysis of recombination across the centromere itself and provide data indicating a significantly lower exchange rate at the centromere than the average rate of female meiotic recombination on the human $X$ chromosome. In the current climate where much attention is focused on centromere research, this work provides both useful information and a timely reminder for yet another one of the many unique and difficult-to-study properties of the centromere.

The notion that the centromere exerts a direct, negative effect on meiotic recombination both within itself and on proximal chromosomal DNA was recognized $>60$ years ago (Beadle 1932; Mather 1938). This effect, termed the centromere effect, has now been documented in wide-ranging organisms, including Drosophila, Neurospora, Arabidopsis, budding and fission yeasts, tomato, corn, barley, mouse, and human (for references, see Mahtani and Willard 1988; Round et al. 1997). In some of these organisms, the level of recombination suppression at the centromere can be as high as 10- to 40 -fold that of the rest of the genome (Roberts 1965; Tanksley et al. 1992; Centola and Carbon
\end{abstract}

${ }^{1}$ E-MAIL choo@cryptic.rch.unimelb.edu.au; FAX 61-3-9348 1391 .
1994). The determination of recombination rates within the centromeres involves comparison of physical distances across the centromeres with the genetic distances between pairs of centromereflanking markers. Such an exercise is especially arduous in higher eukaryotes as the centromeres in these organisms contain an abundance of tandemly repeated, heterochromatic DNA sequences that vary greatly in array lengths and, therefore, in the precise physical distances they span, even for different members of the same chromosome. An even greater problem is the severe paucity of well-mapped euchromatic DNA markers near the centromere that can be used to measure genetic distances accurately. Despite these difficulties, Mahtani and Willard (1990, 1998) described the use of pulsed field gel electrophoresis to determine the average long-range physical distance across the centromeres of the human $\mathrm{X}$ chromosome. Armed with this information, and using centromere-flanking genetic markers that are sufficiently well mapped, these workers reveal a meiotic exchange rate across the centromere that is at least eightfold lower (colder) than the average estimates on this chromosome. This result therefore provides the first measured value for the level of recombination suppression within the $X$ centromere-a value that closely agrees with that obtained similarly for the centromere of human chromosome 10 in an earlier study (Jackson et al. 1996).

So, why is the centromere such a cold spot for meiotic recombination? The answer to this question is far from clear. Recombination suppression is thought to be the result of the more condensed state of centromeric heterochromatin at the time of crossing-over during meiosis compared with euchromatin (Roberts 1965; Khush and Rick 1967, 1968; Rick 1969, 1972). However, evidence indicating that influences other than heterochromatinization may be involved has come from study of the budding yeast, in which a cloned centromere, although lacking any visible form of heterochromatin, shows decreased recombination when it is artificially integrated into new sites in the genome (Lambie and Roeder 1986). Further evidence has come from observation of the persistence of recombination suppression of centromereadjacent euchromatin in Drosophila even when centromeric heterochromatin is deleted (Yamamoto and Miklos 1977).

Thus, rather than the heterochromatin, it may simply be the centromere activity itself that exerts the recombination suppression effect. Recent studies have demonstrated that centromere activity can be separated from the heterochromatin. During the past 4-5 years, an increasing number of human marker chromosomes have been reported to contain active centromeres (or neocentromeres) that are devoid of the usual centromeric heterochromatin and are apparently formed in euchromatic regions of chromosomes (for review, see Choo 1997). Studies of dicentric human chromosomes in which one centromere has become inactivated have also indicated that the presence of centromeric heterochromatin does not al ways correlate with centromere activity.

As to which specific aspect of the centromere activity is involved in recombination suppression, the answer is again unknown. A good guess is that it probably has to do with the unique chromatin structure that makes up the active centromere. Increasingly, centromere activity is believed to be linked to some centromere-specific, higher-order chromatin organization (du Sart et al. 1997; Karpen and Allshire 1997; Choo 1998; Williams et al. 1998). This belief is highlighted by the identification of a histone H3-like protein, CENPA, that is centromere specific, associates only with active centromeres (Warburton et al. 1997), and is thought to constitute centromerespecific chromatin (Sullivan et al. 1994). In a recent exciting development, Ek- 


\section{Insight/Outlook}

wall et al. (1997) has shown in fission yeast that the assembly of fully functional centromeres is at least partially imprinted by the deacetylation of centromeric histone. The study also demonstrates that histone deacetylation plays a role in the regulation of another unusual property of the centromeric heterochromatin-namely, the transcriptional repression or silencing of marker genes placed within or close to it. At present, it is not known whether the phe nomena of transcriptional repression of genes and meiotic recombination suppression exerted by the centromere are governed by the same mechanisms, perhaps both involving specific modifications of centromeric chromatin of the type described by Ekwall and coworkers (1997).

The study of the mechanisms involved in recombination suppression in humans is not a simple matter, as other than measuring naturally occurring meiotic recombination rates across the centromere, as Mahtani and Willard (1998) have done, it is practically impossible to tamper with the centromere status in human subjects to test specific mechanistic models. The definition of the recombination rates across the centromeres of human chromosomes is an important first step in what is likely to be a long and grueling process of advancing our knowledge on the mechanism of recombination suppression in the human centromere. Although we will continue to find means to gain such knowledge, it is more likely that any such advance will, in the foreseeable future, come from the investigation of lower organisms, in which genetic manipulation is more tenable.

\section{REFERENCES}

Beadle, G. 1932. Proc. Natl. Acad. Sci. 18: 160165.

Centola, M. and J. Carbon. 1994. Mol. Cell. Biol. 14: 1510-1519.

Choo, K.H.A. 1997. Am. J. Hum. Genet. 61: 1225-1233.

1998. Nature Genet. 18: 3-4.

du Sart, D., M.R. Cancilla, E. Earle, J. Mao, R. Saffery, K.M. Tainton, P. Kalitsis, J. Martyn, A.E. Barry, K.H.A. Choo. 1997. Nature Genet. 16: $144-153$.

82 GENOME RESEARCH
Ekwall, K., T. Olsson, B.M. Turner, G. Cranston, and R.C. Allshire. 1997. Cell 91: 10211032.

Jackson, M.S., C.G. See, L.M. Mulligan, and B.F. Lauffart. 1996. Genomics 33: 258-270.

Karpen, G.H. and R.C. Allshire. 1997. Trends Genet. 13: 489-496.

Khush, G. and C. Rick. 1967. Genetica 38: 7494.

1968. Chromosoma 23: 452-484.

Lambie, E. and G. Roeder. 1986. Genetics 114: 769-789.

Mahtani, M.M. and H.F. Willard. 1990. Ge nomics 7: 607-613.

1998. Genome Res. (this issue).

Mather, K. 1938. Genetics 24: 413-435.

Rick, C. 1969. Genetics 62: 753-768.

1972. Biol. Zentralbl. 91: 209-220.

Roberts, P. 1965. Nature 205: 725-726.

Round, E.K., S.K. Flowers, and E.J. Richards. 1997. Genome Res. 7: 1045-1053.

Sullivan, K.F., M. Hechenberger, and K. Masri. 1994. J. Cell Biol. 127: 581-592.

Tanksley, S., M. Ganal, J. Prince, M. de Vicente, M. Bonierbale, P. Broun, T. Fulton, J. Giovannoni, S. Grandillo, G. Martin et al. 1992. Genetics 132: 1141-1160.

Warburton, P.E., C.A. Cooke, S. Bourassa, O. Vafa, B.A. Sullivan, G. Stetten, G. Gimelli, D. Warburton, C. Tyler-Smith, K.F. Sullivan et al. 1997. Curr. Biol. 7: 901-904.

Williams, B.C., T.D. Murphy, M.L. Goldberg, and G.H. Karpen. 1998. Nature Genet. 18: 3037.

Yamamoto, M. and G. Miklos. 1977. Chromosoma 66: 71-98. 


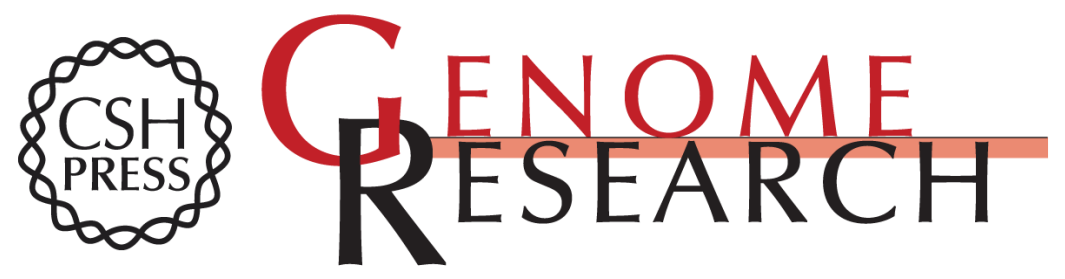

\section{Why Is the Centromere So Cold?}

K.H. Andy Choo

Genome Res. 1998 8: 81-82

Access the most recent version at doi:10.1101/gr.8.2.81

References This article cites 21 articles, 7 of which can be accessed free at:

http://genome.cshlp.org/content/8/2/81.full.html\#ref-list-1

\section{License}

Email Alerting Receive free email alerts when new articles cite this article - sign up in the box at the Service top right corner of the article or click here.

\section{Affordable, Accurate Sequencing.}

To subscribe to Genome Research go to:

https://genome.cshlp.org/subscriptions 